\title{
External Account and Foreign Debt Management
}

\author{
Ashfaque H. Khan"
}

\begin{abstract}
The paper highlights strong gains in the macro area. The author also shows how total debt as a percentage of GDP has declined from 100\% in 2000 to $61 \%$ in 2005. This had resulted from a debt restructuring with the Paris Club in 2001 and also due to the re-appraisal of GDP, which has lowered the debt burden as well.
\end{abstract}

We should first focus on the external account, which is very topical in both newspapers and TV. The trade deficit has widened significantly. It is therefore very appropriate to understand what is the external balance. Should we worry about it widening? Should the country across our border also worry, because they are also facing a greater deficit?

Since I think it is very important, the first item of this presentation will try to clarify what is debt. There is a lot of confusion and contradictions. Why should we examine the two debts separately? Why has Pakistan landed in such a difficult debt situation? What has been the debt management strategy? Where are we now? Where do we want to go in the next five years?

Let us start by looking at the trade gap. The trade gap is one component of the overall balance of payments. It is the gap between merchandise exports and merchandise imports. There is also the service gap, between export services and import services. We then add the trade and services gap to arrive at the trade balance. Then there are flows and private transfers which include remittances and official transfers. But when we report our current account deficit, generally we exclude official transfers. So these transfers offset the gap in the trade account and the gap in the services account.

\footnotetext{
* Director General (Debt Office) \& Economic Advisor, Ministry of Finance, Government of Pakistan. This paper was compiled from the audio-video recording of the Conference by the Editors and Co-Editor.
} 
After adjusting, if the transfers are greater than the two accounts, then there will be a current account surplus and if the transfers are less than the two gaps, then there will be a current account deficit, which is equivalent to the budget deficit in our internal account. Once we have a deficit in our current account or budget account, we need to fill this gap in the current account, and this is what is known as the capital account.

So in the balance of payments we have a current account deficit and then amortization payments. This is basically composed of the principal payments on the debt we have incurred in the past. There are minor other payments as well. So what is the total requirement for any country? We need to fill the current account gap, and then we have to spend on amortization payments and other payments. What is the total financial requirement? We fill this gap through the capital account.

There are two types of entries into the capital account: non debt creating inflows and debt creating inflows. Remember we are now borrowing to fill the requirements - the requirements of the current account deficit, requirements of amortization payments, and other smaller payments.

What are the elements that enter into non-debt creating inflows? They are Foreign Direct Investment (FDI), portfolio investment, and grants that we receive on different government accounts. These are basically general depositor receipts, and a kind of privatization. These elements are non-debt creating inflows.

What are the debt creating inflows? Program and project inflows that we get from the World Bank, Asian Development Bank and Eurobonds to raise money. With these inflows we try to fill the financing requirements, the current account deficit, the amortization payments and other payments. Now if the entire capital account is greater than the total financial requirements, there is a balance of payments surplus and there will be a net addition to last year's reserves. If the capital account is less than the total financing requirements, then there is an overall balance of payments deficit and there is a financing gap that we have to finance through borrowings (debt-creating and non-debt creating inflows). If that is the situation, then the country may require balance of payments support. And then we go to the International Monetary Fund (IMF) for this balance of payments support. In other words, if our financing requirements are not fulfilled through all these inflows, then we go to the IMF.

We have been a prolonged user of IMF resources. Where do we stand today in FY 2005-06? Our trade gap is somewhere around $\$ 6.8$ 
billion. Our service gap is close to $\$ 7$ billion and our total gap is $\$ 13.8$ billion. These are our estimates for FY 2005-06. Private transfers are almost $\$ 8.5$ billion. We have not included official transfers - we are considering the current account deficit excluding transfers. So what is our current account deficit? $\$ 13.8$ billion minus $\$ 8.49$ billion which is approximately $\$ 5.35$ billion. This is our current account gap.

What are the other financing requirements? The amortization payments are $\$ 1.04$ billion. This is the principal payment to be made this year. In addition, there are other payments amounting to $\$ 416$ million. Therefore our total financing requirements are $\$ 6.8$ billion. This includes $\$ 5.35$ billion current account deficit, $\$ 1$ billion amortization payments, and $\$ 416$ million of other payments. So we need $\$ 6.8$ billion.

Is this $\$ 6.8$ billion coming to Pakistan? We will be getting about $\$ 4.8$ billion in non-debt creating inflows. We have already received this in our first 9 months. Portfolio investment is $\$ 415$ million, and will be somewhere between $\$ 600$ and $\$ 700$ million this year. Grants are $\$ 637$ million GDR while we were targeting \$ 700 million.

Total non-debt creating inflows are $\$ 4.8$ billion and debt-creating inflows \$ 3.69 billion which includes project and program aid from the IMF, World Bank and ADB to the extent of $\$ 2.9$ billion which already includes bonds of $\$ 3$ million. Therefore total inflows are $\$ 8.5$ billion while total financial requirements are $\$ 6.8$ billion, leading to a balance of payments surplus of $\$ 1.7$ billion. This $\$ 1.7$ billion will be added to our last year's stock of reserves. At the end of the fiscal year, reserves will be more than $\$ 13$ billion.

Is this important? We only looked at one element, that is the trade gap. But it is important to ask: Is it a phenomenon that is unique to Pakistan? You will be surprised that in India this year, (the fiscal year ending on $28^{\text {th }}$ March), India had a current account deficit of close to $3 \%$ of GDP, or about $\$ 30$ billion which was the highest in the last 15 years. What explains the present situation? The reason is that India's economy is also growing and developing countries' economies are import dependent. We need raw materials, we need capital goods, and we need intermediate goods. So as the economy expands, as the pace of economic activity expands, import requirements become larger and larger. As long as we have inflows to finance this gap, there is no problem. We are expanding our production base with a substantial amount of non-debt creating inflows, which is a positive development. 
What is debt? In very plain language, if my monthly salary is Rs 50,000 and my monthly expenditure is Rs 80,000 in the month of April or May, I will borrow Rs 30,000. Next month, in the month of June, if my earnings and expenditure are the same, I will be again borrowing another Rs 30,000. So my debt to date will be Rs 60,000 and so on. Exactly in the same manner, if the government spends more than its current revenue, it borrows from various sources to finance the budget deficit. The accumulation of past borrowing from domestic sources is known as the domestic debt. Similarly, when a country imports more goods and services than it exports, it borrows from various sources to finance the current account deficit. It also borrows externally for debt repayment, i.e principal repayment and to maintain a certain level of foreign exchange reserves. The accumulation of all such past borrowing in dollar terms is known as the external debt.

Since we not only borrow from domestic sources, but also borrow from external sources to finance our fiscal deficit, the debt has two components: a rupee component and a dollar component. Domestic debt is that portion of the debt through which we borrow domestically to finance the revenue/expenditure gap. But if we finance our revenue/ expenditure gap through external resources, it is not domestic debt, but rather it is external debt.

So we have two components of debt: public debt (with a rupee component and a dollar component) and the external debt. Why should we consider these two debts separately? Because the factors responsible for the growth of these two types of debt are different and their consequences for the economy are also different. Public debt poses difficulties for the budget and external debt poses difficulties for the balance of payments.

If borrowing were a bad thing, then there would not be a banking system in this world. If I want to expand my factory, what do I do? I go to the bank, I borrow money, I import machinery, I invest in my factory, I raise my profits, I increase my income and through that increase in income, I repay the interest and principal. This is normal economic activity in a nutshell. In the same way, borrowing domestically or abroad is a normal part of economic activity. As long as the borrower can earn a higher economic social rate of return than the cost of invested funds, then the creation of debt is not a burden. If I borrow money to take my family and travel around Europe and the Middle East, then I have created debt but I did not expand my debt carrying capacity, which is unfavorable. In the past we borrowed to build things that have not increased our debt carrying capacity. Debt servicing problems will arise when the debt carrying capacity of the country does not increase commensurate with the increase in the debt servicing liabilities. 
What do we mean by debt carrying capacity? It is the ability of a country to service its external liabilities within an orderly and stable macroeconomic framework.

When is this a problem? It can be problematic if we borrow short term for a longer term problem. Take as an example if Pakistan borrowed short term to build a dam, which could be a 10 year project. If we were to borrow for a one year or two year period of time, there would be gaps in the process and serious cash flow problems. Countries most often run into difficulties because the borrowed funds are directed towards wasteful or low economic return projects. It is not that borrowing is bad, but it is the use of the funds that is important.

Why has Pakistan landed in a difficult debt situation? The reason is that we sustained a very large budget deficit and current account deficit for a very long period of time.

Stide 11 below shows our budget deficits. It has been in the neighborhood of 7 or $8 \%$ of GDP for over two decades. This is a very large figure, twice as high as other Asian developing countries. In other words, for a very long period of time we lived beyond our means. Similarly, on the external account our deficit was close to $5 \%$ of GDP. For a developing country like Pakistan which has sustained such a large gap in the current account for a very long period of time, this is bound to create a debt crisis. Pakistan resorted to distress borrowing and acquired a reputation of a single tranche country.

Slide-11: Budget Deficit as \% of GDP

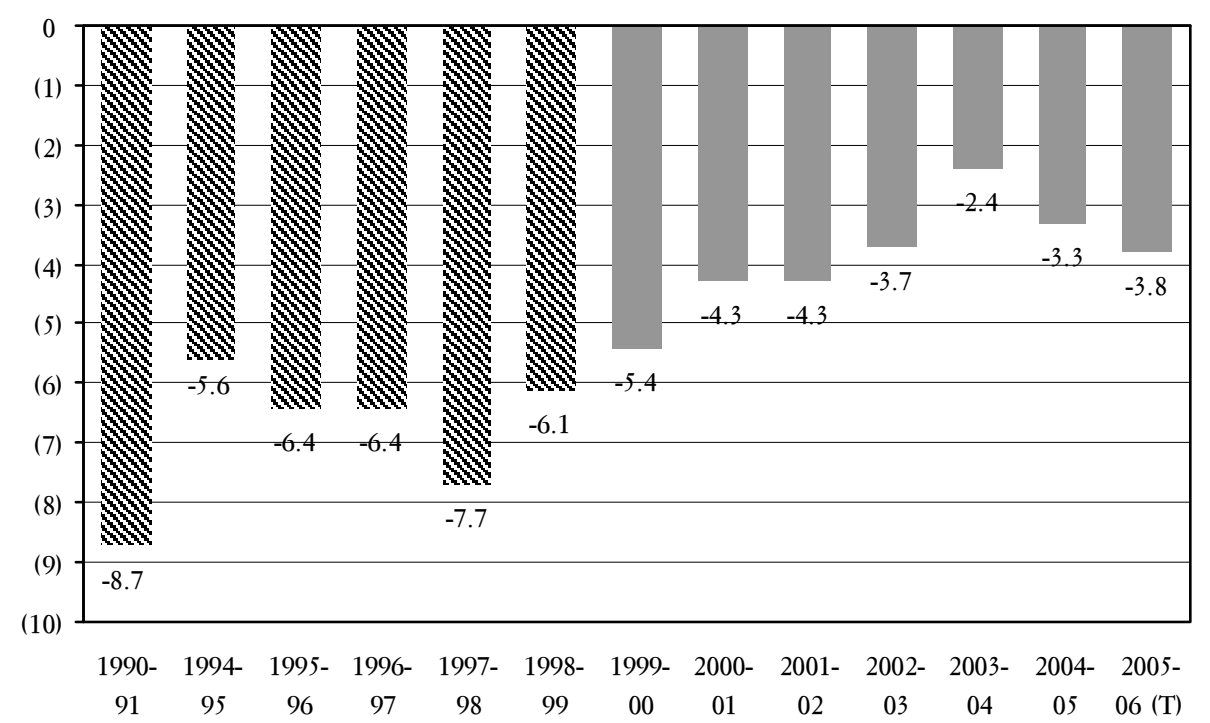


Slide 12 shows the current account deficit. In fact, we need to add 1 percentage point more to the numbers in Slide 12 because we were using foreign deposits. Foreign currency accounts are a financing item of the current account. These foreign currency accounts were the assets of the individual who deposited his money in the bank. It was a liability of the bank. It was transferred to the Central Bank as a liability and the Central Bank used that liability to finance its current account gap.

\section{Slide-12: Trends in Current Account Deficit}

\section{As \% of GDP}

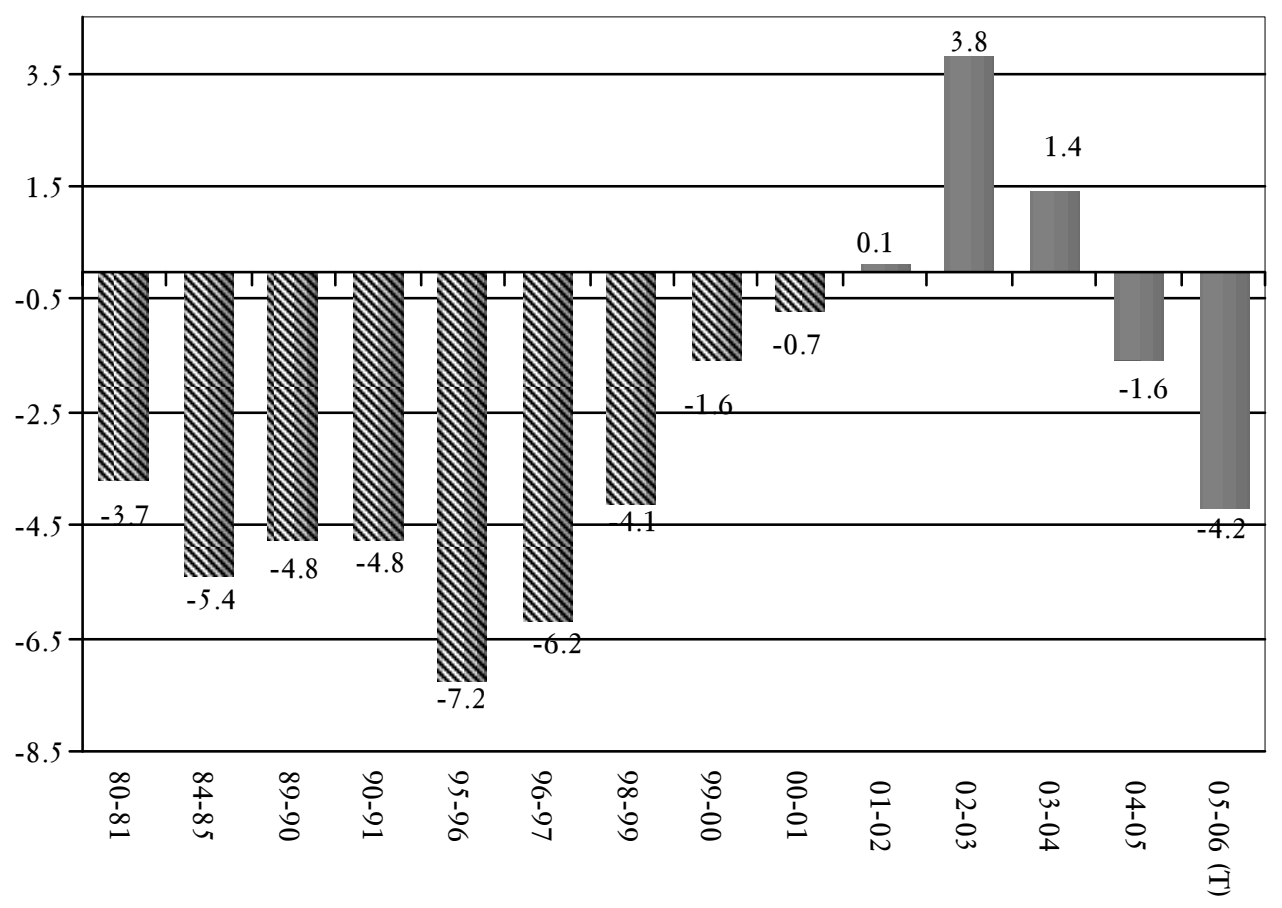

Slide 13 shows the trend in public debt. It is important to note the rupee component and dollar components. Debt payable in dollars multiplied by the exchange rate gives the rupee component of foreign debt. 


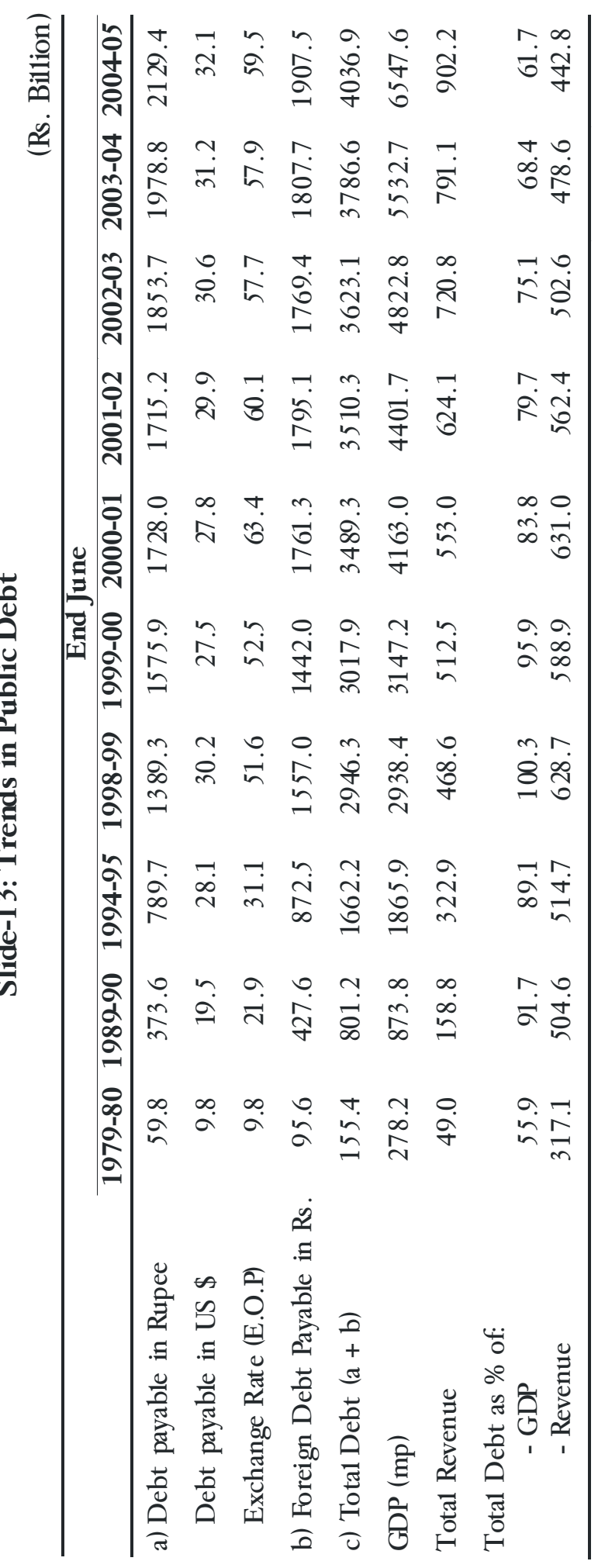


Slides 27 and 28 show the debt as a percentage of revenues and as a percentage of GDP. In order to see the impact of debt, we have to watch both. It is not debt which is bad but rather it is the burden of the debt which is a problem and the burden is measured as the amount of debt - as a percentage of GDP, as a percentage of revenue, as a percentage of foreign exchange earnings and so on. Note here that the exchange rate in 19992000 and in 2000-01 in March was from Rs 62.50 to Rs 63.40.

Slide-27: Public Debt (as \% of Revenue)

(End June)

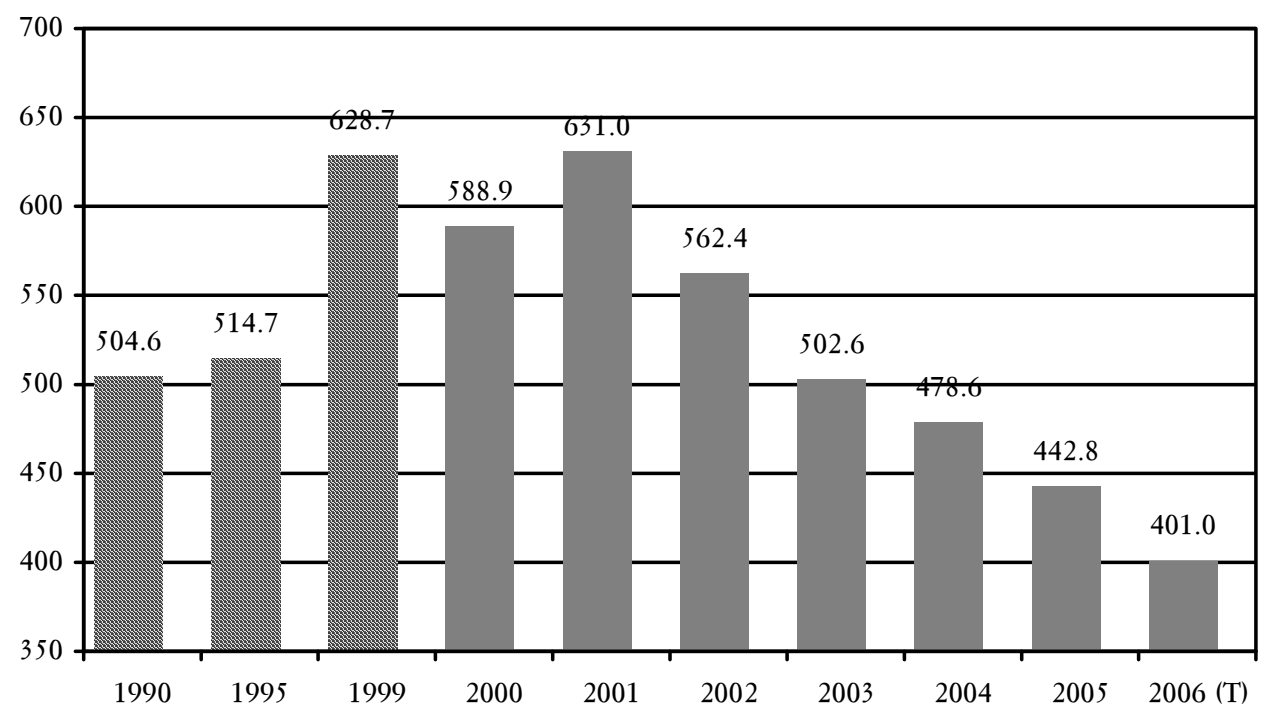


Slide-28: Public Debt (as \% of GDP)

(End June)

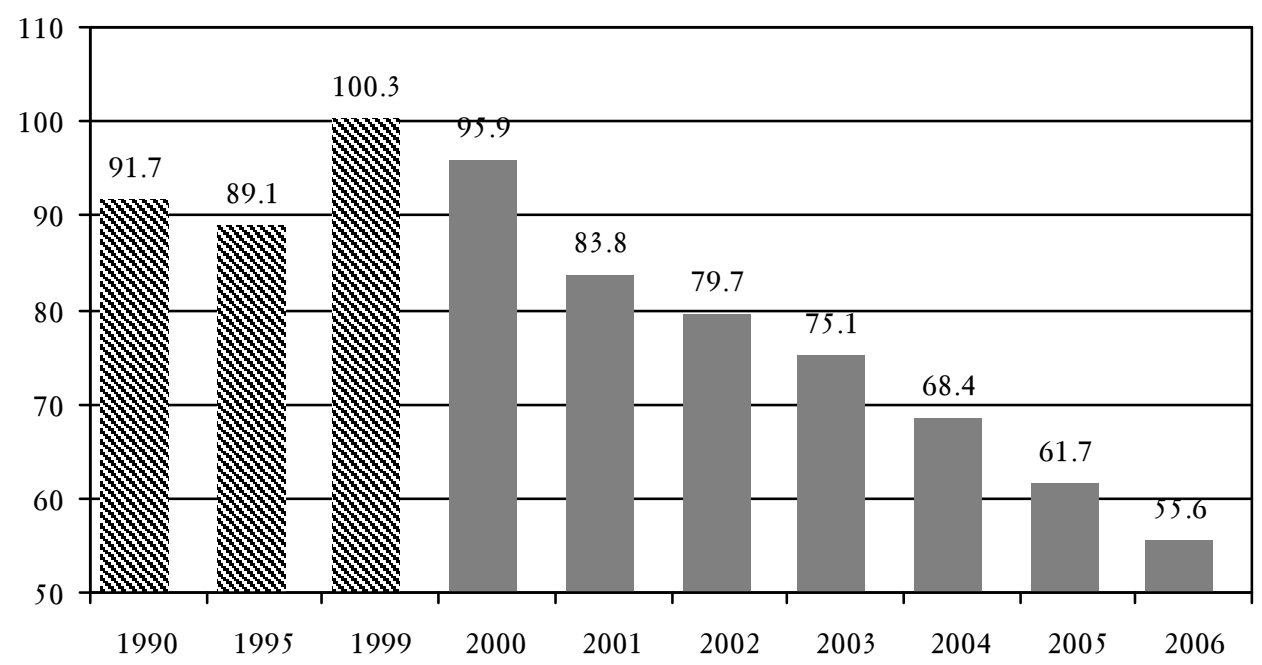

(T)

Slide 13 also shows that looking at the debt payment in dollars, there is hardly any increase, but because of the depreciation in the exchange rate of $18 \%$ in rupee terms between 1998-99 and 2002-03, it added upto roughly Rs 300 million in public debt. This shows that it is important to maintain stability in the exchange rate. Without adding debt in dollar terms we had an increased Rs 300 million in public debt. This is the lesson, demonstrating how our external debt and liabilities grew over the years. In the decade of the 80 s we started with about $\$ 9$ billion and ended with $\$ 21$ billion. Then in the 90s we moved from $\$ 21$ billion to almost $\$ 39$ billion and it was growing at an average rate of $6.6 \%$ per annum. After that there was a slight decline in absolute terms.

Why should we worry about debt problems? We worry because there are serious macroeconomic consequences. First, debt crowded out the private sector. It led to higher interest rates because the government is eager to borrow and both the market and the banking sector will exploit this. We must also consider now how public and private sector investments are complementary. Because of the budget problem, public sector investment was not increasing, and private sector investment was also not increasing. Overall private sector investment declined. We tightened development spending, and we tightened total investment and poverty rose. These are the macroeconomic consequences of unsustainable debt. 
As a result, Pakistan became a prolonged user of IMF resources. Economic policy making centred around the IMF/IFIs' programs. The influence of the IMF and IFIs on policy making increased substantially. This is how investment started declining and how growth started decelerating. As a result the country was severely affected by the debt burden.

What has been our strategy? First we reduced the deficit so that our foreign requirement was reduced. We also reduced the revenue/expenditure gap in addition to the current account gap so that our borrowing requirements were reduced. When our borrowing requirements were reduced, the pace of acquisition of debt declined, raising economic growth. Also a balanced budget is very vital. We tapped resources from the international capital market and most importantly, adopted the Fiscal Responsibility and Debt Limitation Law.

Slide 24 line shows the budget deficits. It was as low as $2.4 \%$ of GDP. Then we started spending on infrastructure and the deficit moved to $3.3 \%$ of GDP. This year's target is $3.8 \%$ but hopefully will be around 3.5 to $3.6 \%$.

\section{Slide-24: Way Forward: A Prosperous Pakistan}

Continue to Maintain Macroeconomic Stability Sustainable Budget Deficit Ensuing Macroeconomic Stability

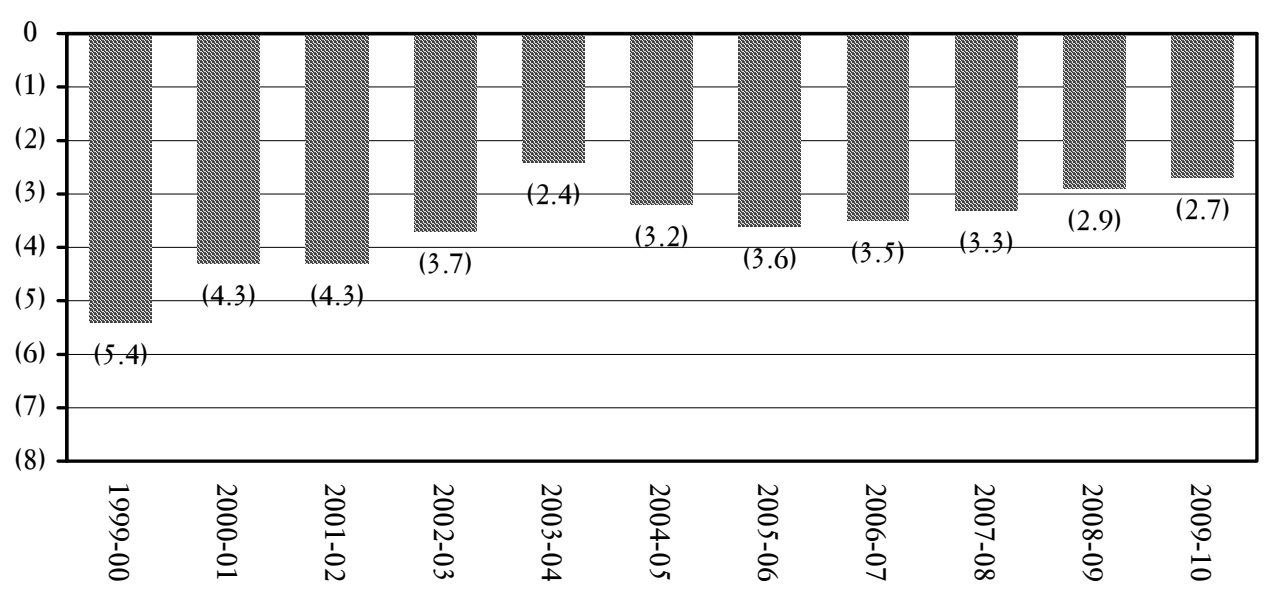

Slide 25 shows that the current account deficit was gradually reduced and for 3 years we maintained a surplus. This is highly unusual for a developing country like Pakistan to maintain a current account surplus. That a country maintains a current account surplus means that the country 
is a capital exporting country and an aid giving country. But that is not the case. We are an aid recipient country not an aid giving country. For three years we observed a very strange phenomenon. It happened across the border as well. Many countries experienced a current account surplus and in the process built up their foreign exchange reserves. We also did this. But now as economic activity started accelerating, and oil prices also started doubling and tripling, our import bill started increasing. Our import bill for raw materials, capital goods, machinery, and equipment started increasing, our trade gap started widening and this year's current account deficit bill is to be around $4.2 \%$ of GDP.

\section{Slide-25: Trends in Current Account Deficit}

\section{As \% of GDP}

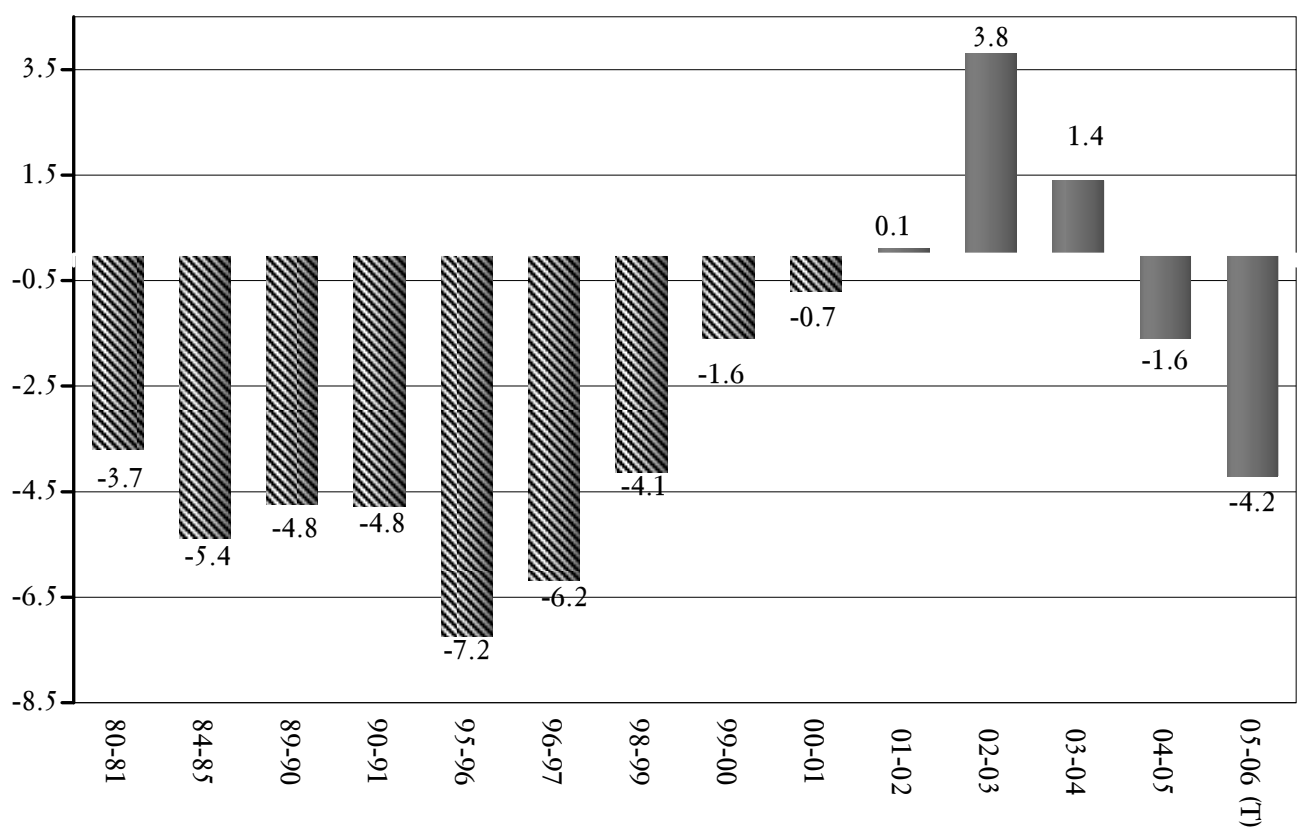

Slide 28 shows how the public debt burden started declining. Our debt was over $100 \%$ and gradually came down to $61.7 \%$ last year and this year, 55.6\%. Our Fiscal Responsibility and Debt Limitation law says that by 2012/13 Pakistan's public debt should be no more than 60\% of GDP and hopefully we will be achieving that target at the end of this fiscal year.

Slide 27 is important because it shows public debt as a percentage of revenue, and it is the revenue through which we will be enhancing our debt 
servicing ability. This percentage used to be around $631 \%$, now it is $400 \%$ this year, a substantial reduction.

\section{Debt as foreign exchange liabilities.}

Similarly, we can look at our foreign exchange liabilities. Slide 29 shows that if the trend that persisted in the 90s when our external debt and liabilities were growing at an average rate of $6.6 \%$, our total debt at the end of last year would have been $\$ 57$ billion. Actually, it turned out to be somewhere around $\$ 35$ billion. So the country was saved around $\$ 21$ billion.

Slide-29: Trends in External Debt and Liabilities

\section{External Debt and Foreign Exchange Liabilities (Billion \$)}

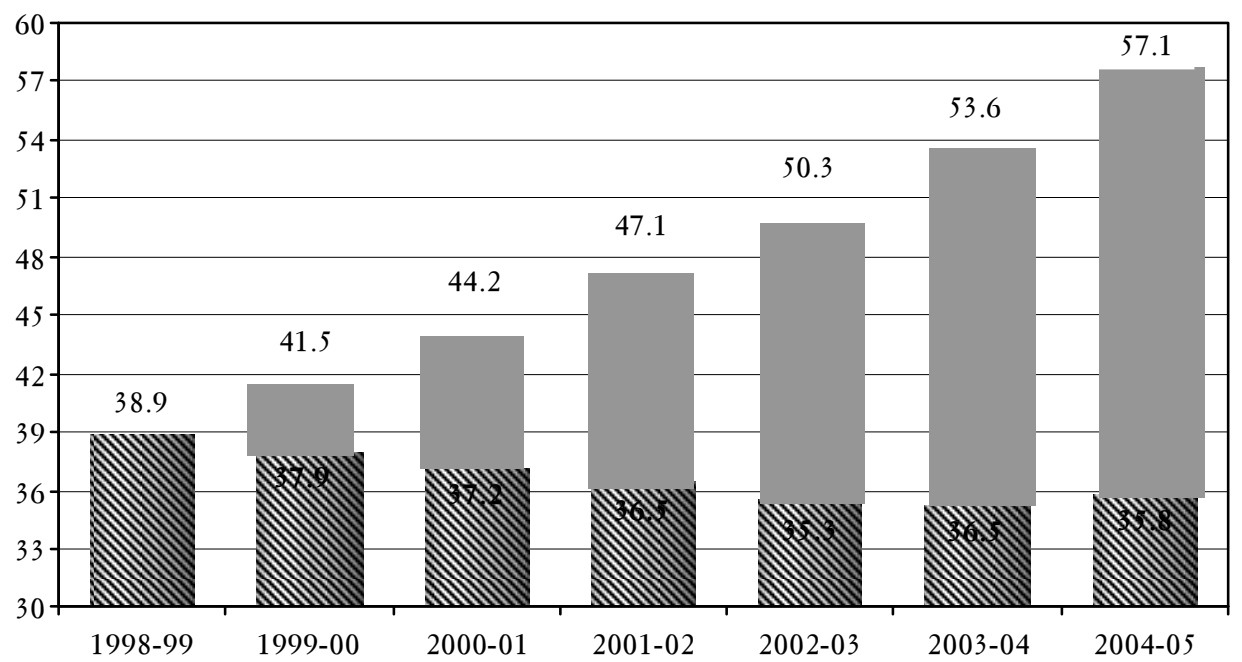

Slide 30 shows the external debt as a percentage of foreign exchange earnings. This was $347 \%$ and came down to $137 \%$ in $2004-05$. With this $347 \%$ of debt burden we were in the league of Heavily Indebted Poor Countries (HIPC) such as Rwanda, Malawi and the Congo. We never declared ourselves a HIPC country for strategic reasons, though at one time we were debating whether we should declare ourselves a HIPC country. Just like a person having a blood pressure of over 200 means that there is a serious risk of a heart attack, the $347 \%$ figure discussed above showed that Pakistan could default at any time and in fact we defaulted. Now we are out of that dangerous situation. 


\section{Slide-30: External Debt and Liabilities \\ (\% of Foreign Exchange Earnings)}

\section{Significantly reducing vulnerability to external shocks}

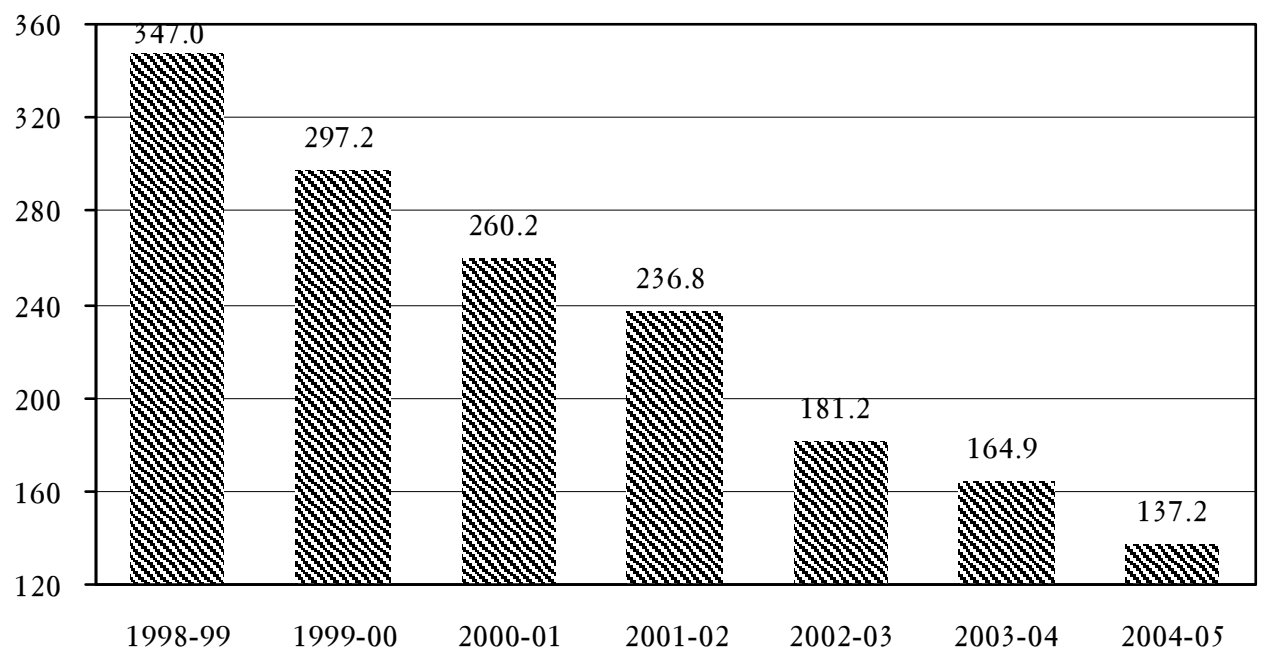

Another way to look at the debt burden is the debt to GDP ratio shown in Slide 31. Similarly, Slide 32 shows that our external debt was 38 times our reserves in the $1990 \mathrm{~s}$ and came down to 2.8 times. Now as a result of the declining debt burden, we are witnessing an acceleration in economic activity. Slide 37 shows that GDP growth, economic growth, is moving upwards. We are now in the $6 \%$ to $8 \%$ mode and in the next 5 years, that will be our trend line. Therefore we want to maintain this macroeconomic stability. Our immediate plan is that we must grow at an average rate of $6.5 \%$ to $8 \%$. This range exists because we rely on an unpredictable agricultural output. This output is dependent on four crops, that account for $30 \%$ of agricultural output, which in turn is dependent on Mother Nature. 
Slide-31: Indicators of Debt Burden

External Debt (As \% of GDP)

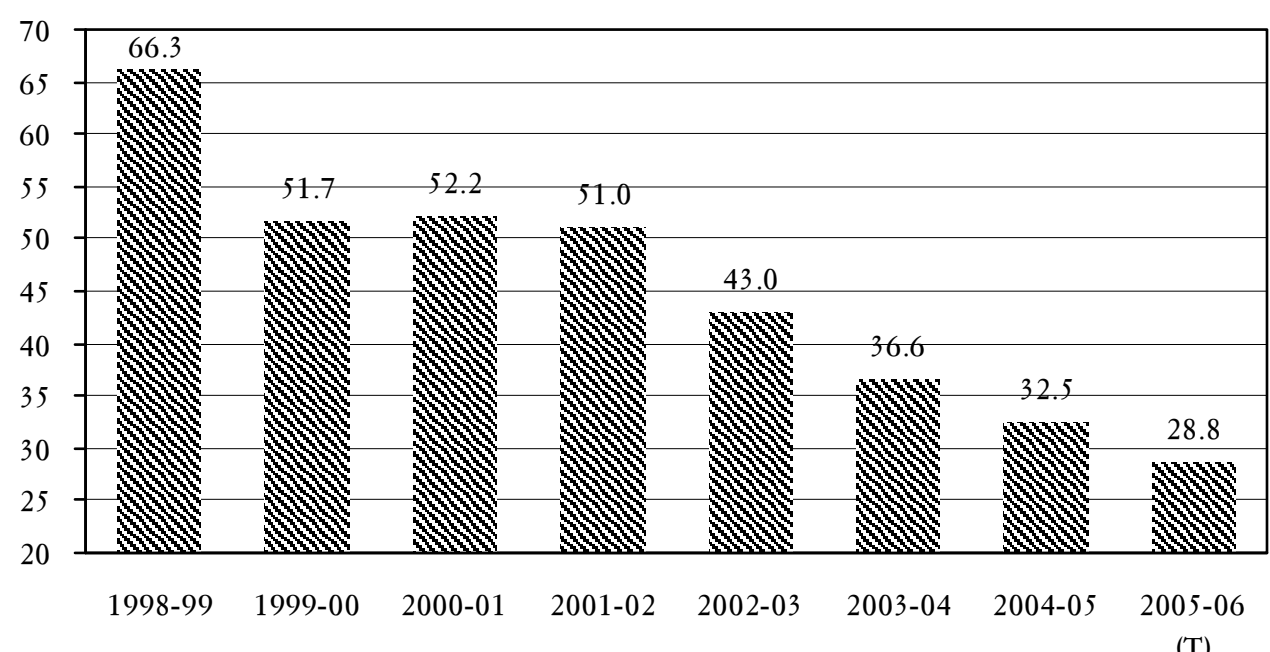

Slide-32: Indicators of Debt Burden

External Debt as Multiples of FX Reserves

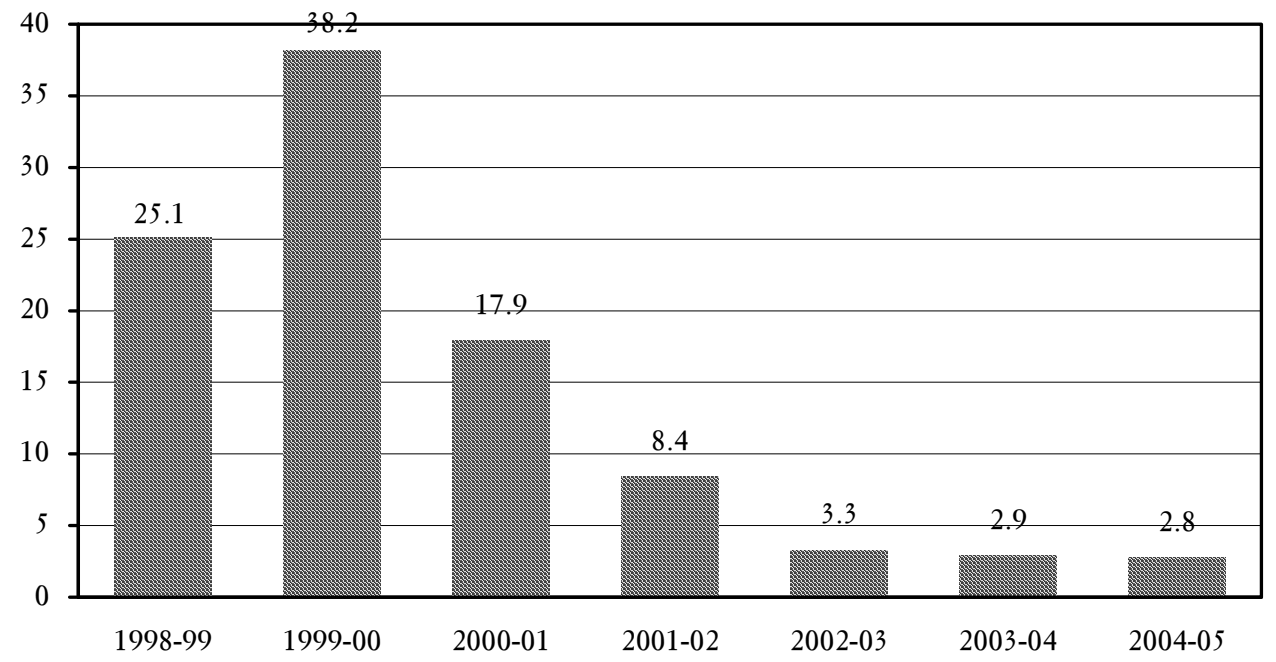


Slide-37: Economic Growth Picking Up

Real GDP is maintaining a robust upward trend

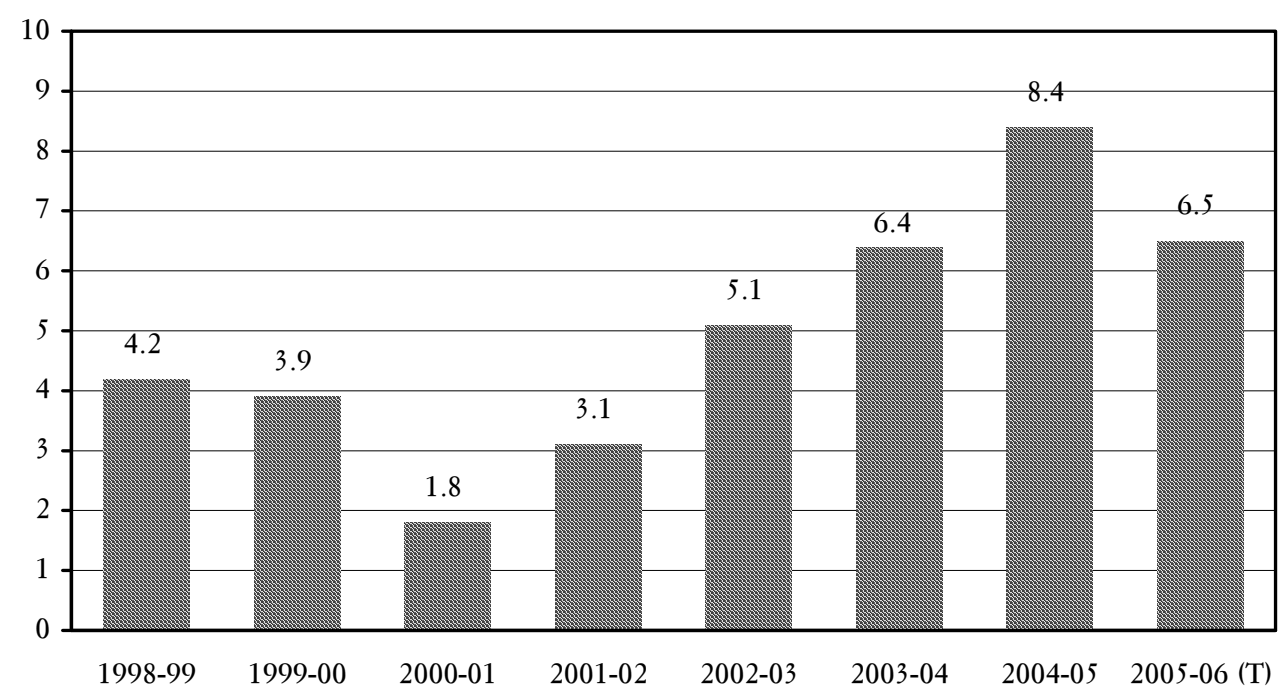

The fiscal deficit will remain close to $3 \%$ of GDP in the next 5 years. This is on target. And if we maintain this deficit our public debt path will be close to $40 \%$ of GDP by $2009 / 10$. This is very safe as far as the debt burden of the country is concerned.

Regarding our the external debt situation, If we maintain the same type of growth for exports and others, our external debt will decline to $22 \%$ of GDP.

The way forward for Pakistan is to maintain financial discipline by keeping the budget deficit to $3 \%$ of GDP. We must also keep our current account deficit to below $3 \%$ of GDP. At the same time, we must maintain a stable exchange rate in order to keep the level of debt manageable. We must also keep inflation low because if inflation is low it will help maintain stability in the exchange rate. It will attract FDI, which are non-debt creating inflows. We can finance the current account deficit without any increase in the debt burden. If inflation is low, the interest rate will also remain low. It is important to move from donor driven to need based borrowing. We need to figure out how much money we require to maintain growth at 6 to $8 \%$ per year. And we should also figure out a borrowing strategy that is consistent with macro financial stability. As for our reserves, there should be a currency mix. So far there has only been a concentration on the dollar. We should also keep the Euro, Yen and other currencies in 
our reserves. We must also consider the level of our current account deficit. We must also ask: What are our amortization payments? Is there any target for reserve targets? What are our medium term development priorities? We have to keep these indicators in mind when we determine our borrowing requirements.

\section{Concluding Remarks:}

To reach where we are today took six years of sustained efforts and sacrifices. To slide back takes no time. This is the lesson we must remember. Everyday there are major shocks coming from different quarters There is no doubt the country's debt burden has declined substantially and is fast approaching a sustainable level. To take the debt situation to a sustainable level we must maintain macroeconomic stability and continue to follow the path of structural reforms. Political stability is also vital. We need a need based borrowing strategy rather than a donor driven strategy. 